\title{
Poverty and Crimes in Nigeria: Indices of Governance Failure
}

\author{
Adeleke Adegbami ${ }^{1} \&$ Charles I. N. Uche ${ }^{2}$ \\ ${ }^{1}$ Department of Political Science, Olabisi Onabanjo University, Ago-Iwoye, Nigeria \\ ${ }^{2}$ Department of Public Administration, Oduduwa University, Ipetumodu, Nigeria \\ Correspondence: Adeleke Adegbami, Department of Political Science, Olabisi Onabanjo University, Ago-Iwoye, \\ Nigeria. Tel: 234-80-3405-6781. E-mail: adeadegbami@yahoo.com
}

Received: September 8, 2015 Accepted: October 20, 2015 Online Published: April 28, 2016

doi:10.5539/par.v5n1p37 URL: http://dx.doi.org/10.5539/par.v5n1p37

\begin{abstract}
Poverty and means of survival has contributed in no small measure to the level of crimes being committed in Nigeria. In our contemporary time, the rate at which crimes are being perpetrated in Nigeria is unparalleled. The nation's problem is not unconnected with weakness in its administrative system; where a few powerful cliques hijacked the administrative apparatus to serve their interests to the detriments of the citizenry. Accordingly, widespread impunity became prevalence among the government actors, corruption thrives, and disease germinates, poverty blossoms, crime breeds, and permeated the nooks and crannies of the nation. The nation's Managers responded to the problem by cosmeticizing the nation's image with the slogan - "Nigerians, good people great nation" a negation or aberration of the popular saying - "a hungry man is an angry man"; instead of giving good governance to the citizenry. It is on this note that the study examined the nexus between poverty and crimes in Nigeria. The study relied heavily on secondary sources of data. The findings of the study revealed that there was correlation between unemployment and criminal practices; many of the youths engaged in crime, to keep their bodies and souls together. The findings also revealed that lack of good governance, vis-a-vis committed; competent; and visionary leadership has contributed to the situation in which Nigerian's youths find themselves; which had earned them names such as - bunkers, hooligans, kidnappers or hostages' taker, internet fraudsters, drug peddlers, and prostitutes. These nefarious activities have led many of them into Prison. The implications of crimes and criminal activities on Nigeria and Nigerians included - psychological trauma on victims, victims' relations, and people within the areas of crimes. Some victims suffer loss of vital organs or parts of their bodies; permanent disability; or even premature death, which consequently, turning members of the society into orphans, widows and widowers. Crimes and criminal activities also brought about, lower quality of life; loss of incomes; properties; relocation or closure of businesses and markets; increase in security budget; and damage in the image of the country. The study concluded that, since Nigeria's leaders appear incapable of providing appropriate solution to the menace, expatriate could as well be hired as it has being done to other business activities of Nigeria.
\end{abstract}

Keywords: poverty, crimes, governance, nation's managers and corruption

\section{Introduction}

It is not in doubt that Nigeria is blessed with numerous natural/mineral resources, despite this, poverty is daily ravaging its people. Poverty and means of survival has contributed in no small measure to the level of crime being committed in Nigeria. In our contemporary time, the rate at which crimes are being perpetrated in Nigeria is unparalleled, as its being committed intermittently across the nation. Cases of crimes and criminal activities are being reported on daily basis through the mass media especially as it affects individuals; communities; states and the nation at large. Crimes and criminal activities cover different parts of the nation, from the North to the South and from the East to the West.

Crime has become a real problem to the nation, especially; its effect on the wellbeing of citizenry and nation's developments. Commenting on the level and nature of crime in Nigeria, Alemika (2011:13) asserts thus

There are four important indicators of whether or not a country has a crime problem. These indicators are the extent, seriousness and pattern of crime, and the control capacity or effectiveness of crime control institutions. Based on these indicators, Nigeria has a crime problem because the country's crimes are serious 
and of diverse kinds.

Crimes and criminal activities continue to flourish in the nation as a result of weakness in Nigeria's administrative or governance system. For instance, the administrative mechanism is being hijacked by few powerful elite who continually serving their own interests instead of the interest of the citizenry. These few powerful elite have cornered "national cake" into "personal cake", and national wealth to personal wealth. This system of governance seems unacceptable to the citizenry; especially, the most vibrant sect of the population; the youths, who are now reacting in the "only way" they know.

Any nation of the world that intends to overcome violence; or organized crimes must above all other things suppress poverty among its citizenry. Nonetheless in Nigeria, owing to what could be termed as bad governance - vis a vis the hijacking of governance apparatus by the powerful cliques in Nigeria, widespread impunity became prevalence among the government actors, corruption thrives, poverty blossoms and consequently, crime breeds, and permeated the nooks and crannies of the nation. It is on this note that the study examines the nexus between poverty and Crimes in Nigeria.

\section{The Powerful Cliques and Their Impacts on Nation's Wealth}

Powerful cliques in the context of this study are those who control and dominate the political and economic activities of the nation. In some quarters, they are seen as - god-fathers, political bigwigs, business mogul, oil barons, movers and shakers of the society. These are set of people who are feeding fat on the nation's wealth. They achieve this by allocating oil ridge and oil blocs to themselves, awarding inflated contracts as well as acquiring government properties to themselves. These set of people have properties in choicest areas of the nation and have numerous bank accounts in choicest banks across the world. These are the people who are "above Nigeria's laws"; they are so corrupt morally and socially. Majority of these people are politicians cum businessmen with few traditional rulers and religious leaders in their caucus. They enjoy sharing our commonwealth; turning the national cake into personal cake as well as committing other crimes with impunity.

The Nigerian Legislature is an example of powerful cliques in the nation today, and the issues of sharing our commonwealth and turning the national cake into personal cake played itself out during the $7^{\text {th }}$ National Assembly. It will be recalled that Mallam Sanusi Lamido Sanusi, the immediate past Governor of Central Bank of Nigeria, declared unequivocally that the Nigeria's National Assembly in 2010 spent 25 percent of the recurrent expenditure of the Federal Government's budget. Even when Sanusi was summoned to justify his claim before the Joint Committee of the House on Finance, Appropriation, Banking, Currency and Narcotics, Drugs and Financial Crimes, he maintained his ground to the amazement of Nigerians. According to Sanusi as cited in The Nigerian Voice, (2010)

The National Assembly's overhead in this year's budget is N136 billion...then N136 billion is $25 \%$ of the Federal Government Overhead (The Nigerian Voice, 2010).

Similarly, Sanusi (2015) went further concerning the level of wealth accumulation by Nigeria politicians without taking into consideration the hapless and helpless teeming masses, believed to have voted them to power. Sanusi (2015:1) states unequivocally that

The biggest problem in National Assembly, NASS, is not the salaries or allowances. It is a very big item in the NASS budget called overheads. What they do is pack that item in the appropriation bill and then "collapse" it according to a pre-agreed formula. A certain percentage is shared among the leadership. Another portion is given to the management to cover genuine overheads. The rest is shared among members. I believe early in Obasanjo's term the overhead budget of NASS was like N10 billion. By 2011, when I raised an alarm, it was N126 billion and 25\% of the entire overhead budget of the Federal Government. When I drew attention of the country to this, many people did not understand why NASS was angry. It is because, they were sharing the money that was not spent on NASS overheads, and they have a perfect system now for "retiring" it. There is an entire structure within NASS whose job is preparing receipts vouchers etc to cover this item...

Similarly, James Ibori was one of the cliques that involved in plundering the nation's wealth. His eight years in office, from 1999 to 2007, was considered counter-productive, in terms of provision of social amenities for the state. Several billion dollars of oil revenue go directly into his pocket, while "the state's public schools crumbled, while primary health clinics remained dilapidated and lacked basic supplies and medicines" (Human Rights 
Watch, 2012). Ibori was above the law of Nigeria; he walked tall throughout his staying in Nigeria; while the law of the land became a toothless bulldog that cannot bite him. However, Ibori fell under the powerful law of England, as he pleaded guilty in a London court to have stolen a whooping sum of $\$ 79$ million which could have been used to better the lives of the people in the community.

Similarly, The Royal Bank, Scotland, while assisting the Metropolitan Police in gathering evidences on "corruptive activities" of some notable Nigerian, exposed some of the illicit transactions of Alamieyeseigha another member of the powerful cliques. According to them, Alamieyeseigha holds a personal account with the Barclays Bank Plc. and the account balance as at 15th February, 2005 stood at $£ 203,753$. 34. He (Alamieyeseigha), according to the Metropolitan Police, also purchased

four London Properties namely: 247 Water Gardens London, W2 2DG
purchased on 20/08/2003, 14 Mapesbury Road London, Nw 24 JB purchased
for $£ 1.4$ million, on 6/7/2001; Flat 202 Jubilee Heights, Shoot up Hill, London
NW2 3UQ purchased for $£ 240,000.00$ and $68-70$ Regent Park Road, London,
N3 purchased for $£ 3$ million were found to be registered in the company's
name. The Conveyancing file for the purchase of 247 Water Gardens shows
various sources of funds but one transaction emanated from Triumph Bank Plc
in Nigeria. The transfer was for $£ 894,990.00$ on the $3 / 7 / 2005$
(http://www.sharpedgenews.com, 2013).

What a way to make people suffer in the midst of plenty! If only Ibori and Alamieyeseigha could embezzle and pocket as much as aforementioned public money, what hope do the youths have? Is this not a case of mortgaging the future of youths; and even unborn children?

\section{Unemployment and Criminal Practices among the Youth}

There is a clear correlation between unemployment and criminal practices. Perhaps many of the youths engage in crime as economic activities in order to keep their bodies and souls together, a case of devil finds works for an idler. These nefarious activities in which the youths engage in, consequently led many of them into the prison. According to Adebayo (2013) the youths supposed to be the driving force for development, conversely in Nigeria; the youths are becoming volatile, because they have their energies misdirected, since they do not have a better engagement to which they could apply their energy.

Lack of good governance vis-a-vis committed; competent; and visionary leadership has contributed to the situation in which Nigeria's youth find themselves today. Even with the abundant mineral/natural resources of the nation, a large number of unemployed youths continued to increase. The attendant effect of lack of good governance is poverty which continues to thrive among the citizenry, of which concomitant effect is insecurity; and threat to human existence. According to Agu (n.d:387) 'life in Nigeria is almost becoming nasty, brutish and short, and there is palpable state of anomie as it were, and national security is in jeopardy'. Many of these youths are well trained academically and professionally, their inability to get job often lead many of them into engaging in shady activities such as - bunkering, kidnapping or hostages taking, internet fraud, drug peddling, and prostituting.

Some of the youths also engaged in internet scam. Through internet they do introduce different kind of businesses to their victims. A lot of people, both local and international have been duped of their money through this means. Some of these youths; end up in the centre of Prison whenever they are caught, while those who have not been caught continued in the "enterprises".

One of the funniest responses at tackling the problem by the government is the image laundering of the nation. Instead of providing good governance with indices of: accountability - where leaders are answerable to the led, and be made to be responsible for their action(s) and inaction(s) while in the office; transparency - a situation whereby governmental businesses are transacted openly, in a manner that allow the citizens to ask questions bothering on governmental activities, policies and programmes; the rule of law - this involves applying the Constitution in all the nation's activities and in all areas of governance; and participation - a situation of allowing the civil society to partake in the formulation of governmental policies and programmes of development that will affect them (see International Development Association, 1998, as cited in International Fund for Agricultural Development, 1999), Nigeria government was cosmeticizing the nation's image with the slogan - "Nigerians, good people great nation".

The slogan is a total negation or aberration of the popular saying - "a hungry man is an angry man". One needs to ask, how could a country with the population of 163 million out of which 112 million are living in abject 
poverty (as cited in Omoyibo, 2013), be good people? How on earth could unhappy citizens who suffer hunger and insecurity make a great nation? Or how could a nation with bad governance be great? The image laundering by the government is tantamount to plundering the remnant resources of the nation; effort in futility and fruitless exercise which further traumatising the already dehumanising downtrodden citizens of the country. It is indeed a misplaced priority and evidence of lack of vision by the nation's Managers.

That great American comedian and actor, Groucho Marx whose real name was Julius Henry Marx (1890-1977), must have had Nigeria's type of politics and politicians in mind when he defined politics as the art of looking for trouble, finding it everywhere, diagnosing it incorrectly, and applying the wrong remedies" (Marx, n.d.). This definition aptly suited Nigeria's socio-economic and political situations. For instance, Nigeria's problems are self- instituted one; which could have been prevented if the nation's Managers have been proactive enough in handling the affairs of the nation. Now the problem has breeds and permeates every nooks and crannies of the nation. And till date; there is no sign of solution to the problems; as the nation Managers appear incapable; without adequate knowledge of administration, or that the nation is too complex for them to govern.

Whenever there are few jobs in the Ministries, Departments and Agencies (MDAs) of Nigeria, hope of the youths normally rise, but the hope is dashed almost immediately. The MDAs leadership are always the problem. There are a number of times when they ask job seekers to pay certain amount of money before they could register online for jobs. The MDAs leadership apart from the issue of online registration have also asked job seekers to pay for jobs. Type or juicy nature of the job determines its price. To this extent, many of the unemployed youths do go extra miles to get money "to purchase" their types of jobs. Many of these desperate youths do find themselves perpetrating crimes in order to purchase their much needed jobs. In 2013 for instance, thirteen (13) Federal Ministries, Departments and Agencies (MDAs) were exposed on account of irregularities in the recruitment in their various organisations. These MDAs include the Ministry of Interior, the Federal Airports Authority of Nigeria (FAAN); the Nigerian Airspace Management Agency (NAMA); the Independent National Electoral Commission (INEC); the National Examination Council of Nigeria (NECO); the Joint Admission and Matriculation Board (JAMB); the Nigeria Civil Aviation Authority (NCAA) and the Nigeria Meteorological Institute. Others include the Nigeria Security and Civil Defence Corps (NSCDC); the Federal Road Safety Corps (FRSC); the Nigeria Immigration Service (NIS); the Nigeria Customs Service (NCS); and the National Youth Service Corps (NYSC). The Chairman, Senate Committee on Federal Character and Inter-Governmental Affairs as well as the Senate President, at the public hearing on the issue, attested to the irregularities, and acknowledged the receipt of lots of petitions from aggrieved individuals (Folasade-Koyi, 2013).

It will be recalled again in 2014 , that one of the youths in his desperate bid to get job had to falsify a reference/recommendation letter in the name of the Minister of Finance and Economic Planning and the Coordinating Minister of the Economy, Dr. Ngozi Okonjo-Iweala. The incident was exposed when the young man; a graduate with a Higher National Diploma certificate from one of the Nigeria's polytechnic got arrested by the Economic and Financial Crimes Commission (EFCC). The young man had earlier applied for jobs in his three choicest places - the Economic and Financial Crimes Commission (EFCC), Tertiary Education Trust Fund (TETFUND) and the Nigerian Security Printing and Minting Company (NSPMC), and presented the said letter to the management of the mentioned government's establishments before he was arrested. The young man perhaps must have realized that in Nigeria; jobs are for those who know, or have connection with the few cliques in high places of Nigeria's administration.

The above scenarios have vividly shown the effects or implications of bad leadership on the innocent youths of the nation. Bad leadership has contributed to moral decadence; moral laxity in Nigeria's youths; integrity has already being thrown into the waste-being, a case of when the head is rotten, the whole body is affected.

\section{Wealthy Nation with Poverty Stricken Populace: A Paradox}

One wonders if there could be any explanation for the high level of poverty among Nigeria's populace, especially if viewed from the perspective of enormous wealth of the nation. There is no denying the fact that Nigeria is bequeathed with massive mineral resources, especially crude oil; out of which Nigeria is generating far more than $90 \%$ of its annual income as well as foreign exchange. Omoyibo (2013) has lamented concerning the nation's wealth and high rate of poverty, that; despite Nigeria's economic growth and its abundant natural/mineral resources, a large number of its citizens are wallowing in abject poverty. The astounding disclosure by the National Bureau of Statistics, cited in Omoyibo (2013); that, Nigerians living in poverty are 112 million out of 163 million population has lent credence to the fact that Nigeria has failed in its governance system.

It is also interesting to note, that other resources apart from crude oil abound in all parts of the nation. Among 
these natural resources are - marble; clay; cassiterite; gold; dolomite; salt; limestone; lead/zinc; kaolin; bentonite; gypsum; magnetite; uranium; lignite; iron-ore; glass-sand; phosphate; manganese; coal; diatomite; hydro-carbon (oil and gas); gemstone; marcasite; sapphire; serpentinite; asbestos; kyanite; graphite; ruby; rock crystal; and topaz. Others are - copper; talc; columbite; mica; bitumen; beryl (emerald); quartz; zircon; limonite; galena; baryles; feldspar; mica; chalcopyrite; tourmaline; aqua marine; tantalite; tin; pyrochlore; wolfram; bismuth; fluoride; bauxite; silica-sand; laterite; potash; flakes; soda ash; and cotton (Gyang, Nanle, and Chollom, 2010).

With the availability of all these resources embedded in Nigeria, one is likely to conclude; that the nation in the first place should not have had business with poverty, and that the citizens should be living in affluence and not in poverty. However, the story is otherwise, suffice to say; that solution to poverty in Nigeria is so close, yet so far! The fact that these resources are available to be tapped by the nation makes solution to the problem of poverty so close. On the other hand, the government inability to utilise incomes realised judiciously and appropriately is one problem; while the abandonment of skilled Nigerians in the processing and explorations of the resources is another. These make solution to the problem of poverty in Nigeria so far from being realised. The hiring of the foreigners to take up jobs many of which Nigerians are qualified for is a major setback towards generating employments for the youths. This scenario is succinctly chronicled by Ogah, Fanimo, Shadare, Ebosele, Okere, Adepetun, Lawarence (2011). According to them, the continued influx of the expatriate into the nation is a great problem to the country unemployment situation. The inflow of foreigners into the country is on the increase on daily basis. The foreigners come under the guise of special skills lacking in Nigeria. One is forced to ask, what type of skill is special that Nigerians cannot acquire, going by the track record of Nigerians excelling in all areas of human endeavour across the world?

The ineptitude attitude on the part of the nation's managers perhaps is one of the reasons for the series of kidnapping and hostages-taking of the expatriate as recorded in South-south and South-eastern parts of the county. Ikoh (2011) asserts that kidnapping became veritable venture in Nigeria "when the Niger Delta militants kidnapped foreign oil workers to press home their demand", since then, business of kidnapping has continued to flourish in many parts of the nation.

Another sad story was one of the steps taken by the then nation's Managers to ameliorate the problem; as recorded by the Crystal Magazine (February Edition, 2001) cited in Iyayi (2008). It was reported that the Nigerian Government, for lack of vision, enlisted the support of the American military to combat the Niger Deltans with a view to protecting the expatriate residing in the areas. According to the Crystal Magazine (2001:6)

The government...has entered a military pact with the United States of America. Code-named Operation Focus Relief, the agreement grants concessions to the United States Army to engage in activities that no foreign army has undertaken in Nigeria since the country became independent in $1960 \ldots$ the American soldiers...stationed at NICON Hilton and Sheraton Hotels are also engaged in espionage activities on Nigeria's military capabilities.

The menace of Boko Haram has since reduced the foreigner influx into Nigeria. The case of Boko Haram insurgency even degenerates to these extents partly due to bad governance and government insensitivities to the yearnings of the masses. This is because most of the youths being recruited into the camp of Boko Haram are unemployed, whose future looks bleak. These set of youths might have constituted themselves a thorn in the flesh of the state; having realised; that they may not be able to fulfil their future dreams again; for lack of poor management of the nation.

\section{The Implications of Crimes and Criminal Activities on Nigeria and Nigerians}

Giving the widespread of crimes and criminal activities in Nigeria vis-a-vis armed robbery; advance free fraud; obtaining by false pretence; burglary/stealing; attempted murder; murder; manslaughter; breach of public peace; sexual assault; rape; abduction/kidnapping; forgery; impersonation; child trafficking; oil theft/bunkering and of course the recently added crime, "baby making factory", Nigeria has conveniently secured a place among the nations where crimes rate are high.

The costs and implications of crime on the citizenry and the nation at large are immeasurable; raging from wastage of resources; lower quality of life; loss of life; income; and property; and damaging the image of the country. Other costs of crimes included - psychological trauma on victims, relations and people within the areas prone to crimes.

In recent years, there has been an increase in the occurrence of crime and criminal activities which have 
continued to aggravate fear and tension among the citizenry, especially when it is dawned on the populace that security of lives and properties are no longer guaranteed. The high wave of crime has therefore, negatively affected the socio-economic as well as political activities of the nation (Adebayo, 2013).

According to Eban (2011), criminal occurrences do aggravate emotions and tensions from the people in the society, it brought about - "outrage, sadness, anger, disgust, and shock". For instance, armed robbery occurrences do induce fear in people which may have adverse effect on their health; as well as their socio-economic life. Ikoh (2011) maintains that crime "inflicts severe strain on the social fabric and can lead to moral decadence and the disintegration of the society". Every violent crime is always followed by wounds and injuries which could result into hospitalization of the victims. Victims of criminal activities may suffer shock; damage of vital organs or part of the body and even permanent disability. Besides, violent crime may bring about premature death, and consequently, turn members of the society into orphans, widows and widowers.

On the nation economy, violent crime could drastically affect manufacturing businesses, especially those that depend on raw materials in part of the nation for production. Violent crimes could block sources of raw materials for manufacturing businesses, thereby inhibiting productions as well as marketing of finished products. It could even lead to relocating of businesses environments in order to avoid losses of business properties. For instance, the wave of violent crimes in oil producing areas of the country from time to time does hamper the rate of oil productions. Consequently, the nation does record loss of income, because of the continuous kidnappings of oil workers in the region.

On wastage and increase in security budget, Iyayi (2008) sadly notes, that Nigerian government in the year 2008 budgeted a whooping sum of N444 billion for Niger Delta security. The purpose of this budget was to protect the expatriate in the oil rich Niger Delta areas from being kidnapped. The huge sum of money would have gone a long way to cater for the hapless and helpless masses who are suffering because of the effects of oil spillage in their communities. Kidnapping in the first place might not have arisen if the citizens in the communities had been well catered for. The resources budgeted and used to combating crimes could have been used in strengthening the infrastructural amenities (Nwagboso, 2012), which would have made things easier for the teeming masses, this no doubt could be seen as penny wise; and pound foolish, as the so called "security budget" is nothing but a drain on the nation resources which is preventable under a good nation's managers.

On Nigeria's international image, crimes had continued to give Nigerians a negative image before the International Community. According to Ribadu (2004) cited in Mohammed (2012), Nigerians are always subjected to series of "discriminatory treatments". The type of treatments was as results of suspicion of Nigerians wherever they are sighted in foreign land. Nigerians are considered or seen as criminals by the International Community, hence, they are subjected to a thorough search and screening before foreign agencies.

\section{Summary, Conclusion and Recommendation}

There is no disputing the fact, that Nigeria is richly blessed with numerous natural/mineral resources. This notwithstanding; poverty continues to ravage its citizens. This is because the nation's governance activities had been hijacked by few cliques who are serving their own interests to the detriment of the teeming masses of the nation. As a result, widespread impunity became prevalence among the government actors; corruption thrives, poverty blossoms, crime breeds, and permeated the nooks and crannies of the nation. Lack of committed; competent; and visionary leadership contributed to the situation in which Nigerian's youths find themselves today. Nigerian youths have consequently, earned such names as - bunkers, kidnappers or hostages' taker, internet fraudsters, drug peddlers, and prostitutes. Despite these prevalence crimes and criminal activities, Nigeria's leaders appear incapable of providing appropriate solution to the menace, thus; expatriate could be hired to manage Nigeria as it has being done to other business activities of the nation.

In view of the foregoing, the study recommended that leaders of impeccable character and; of high integrity should always be elected to take charge of Nigeria's administration. This could only be achieved only when; the electorate stand up to their responsibility by rejecting vehemently imposition of candidates by the political party. Citizens must fully participate in the screening and scrutinising of all candidates for elective and selective positions. Awareness must also be created among Nigeria's populace to understand the indices of good governance and always demand for them.

\section{References}

Adebayo, A. A. (2013). Youths' unemployment and crime in Nigeria: A nexus and implications for national development. International Journal of Sociology and Anthropology, 5(8), 350-357. http://dx.doi.org/10.5897/IJSA2013.0452 
Agu, O. B. (2009). Economic crimes and national security: Nigerian perspective. Retrieved May 11, 2015, from http://nials-nigeria.org/pub/OkayBenedictAgu.pdf

Alemika, E. E. O. (2011). Security, criminal justice and criminal victimization. In Alemika, E. E. O., \& Chukwuma, I. C. (Eds.), Criminal victimization, safety and policing in Nigeria (pp. 12-22). Lagos: CLEEN Foundation.

Chukuezi, C. (2009). Change in pattern of female crime in Owerri, Nigeria 1980 - 2000. Current Research Journal of Social Sciences, 1(2), 9-13.

Eban, E. S. (2011). Fear of crime and crime control initiatives. In Alemika, E. E. O., \& Chukwuma, I. C. (Eds.), Criminal victimization, safety and policing in Nigeria (pp. 87-100). Lagos: CLEEN Foundation.

Folasade-Koyi, A. (2013). Cash-for-job scam: Senate indicts 13 Federal Ministries, Agencies. Retrieved May 11, 2012 ,

http://sunnewsonline.com/new/cover/cash-for-job-scam-senate-indicts-13-federal-ministries-agencies/

Gyang, J. D., Nanle, N., \& Chollom, S. G. (2010). An overview of mineral resources development in Nigeria: Problems and prospects. Continental Journal of Sustainable Development, 1, 23-31.

Human Rights Watch. (2012). Nigeria: UK conviction of James Ibori a blow against corruption. Retrieved May 29 , 2013,

from http://saharareporters.com/press-release/nigeria-uk-conviction-james-ibori-blow-against-corruption-humanrights-watch

Igbo, E. U. M. (2011). Corruption in Nigeria: Patterns and trends. In Alemika, E. E. O., \& Chukwuma, I. C. (Eds.), Criminal victimization, safety and policing in Nigeria (pp. 71-86). Lagos: CLEEN Foundation.

Ikoh, M. U. (2011). Criminal victimization in Nigeria: Pattern and trend. In Alemika, E. E. O., \& Chukwuma, I. C. (Eds.), Criminal victimization, safety and policing in Nigeria (pp. 36-70). Lagos: CLEEN Foundation.

International Fund for Agricultural Development (IFAD). (1999). Good governance: An overview. Executive Board - Sixty-Seventh Session of the International Fund for Agricultural Development (IFAD) (1999). Rome, 8th-9th September, 1999.

Iyayi, F. (2008). Niger Delta crisis: Development and socio-cultural implications. Being paper presented at the forum organised by PENGASSAN at Gateway Hotel, Ijebu-Ode on 17th June, 2008.

Marx, G. (n.d.). Brain quote. Retrieved May 30, 2015, from http://www.brainyquote.com/quotes/quotes/g/grouchomar146422.html\#FGycO2HvTsPIPt1D.99

Mohammed, F. (2012). Financial crime and its implications on Nigeria's social image. International Journal of Economic Development Research and Investment, 3(1), 110-113.

Nigerian States and Natural Resources. Retrieved August 4, 2015, from http://www.nairaland.com/724526/nigerian-states-natural-resources

Nwagboso, C. I. (2012). Security challenges and economy of the Nigerian State (2007-2011). American International Journal of Contemporary Research, 2(6), 244-258.

Ogah, D., Fanimo, D., Shadare, W., Ebosele, Y., Okere, R., Adepetun, A., (Lagos) \& Lawarence, F. (2011). Expatriates, some semi-skilled, take over even menial jobs from Nigerians. Retrieved February 2, 2012, from http://www.guardiannewsngr.com/index.php

Omoyibo, K. U. (2013). Leadership, governance, and poverty in Nigeria. Mediterranean Journal of Social Sciences, 4(6), 29-36. http://dx.doi.org/10.5901/mjss.2013.v4n6p29

Omoyibo, K. U., \& Akpomera, E. (2012). Insecurity mantra: The paradox of Nigerian growth and development. European Scientific Journal, 8(15), 132-142.

Sanusi, L. (2015). Members of the National Assembly (NASS) are thieves. Retrieved May 30, 2015, from http://www.elombah.com/index.php/entertainment-news/32566-members-of-the-national-assembly-nass-are -thieves-lamido-sanusi

Sharpedgenews.com. (2013). The Alamieyesegha corrupt enrichment case file at EFCC. Retrieved May 29, 2013, from http://www.sharpedgenews.com/index.php/news/recent-news/2568-the-alamieyeseigha-corrupt-enrichmentcase-file-at-efcc

The Nigerian Voice. (2010). National Assembly spends 25\% of budget. Retrieved May 30, 2015, 
http://www.thenigerianvoice.com/news/40406/1/national-assembly-spends-25-of-budget-sanusi-reaff.html

\section{Copyrights}

Copyright for this article is retained by the author(s), with first publication rights granted to the journal.

This is an open-access article distributed under the terms and conditions of the Creative Commons Attribution license (http://creativecommons.org/licenses/by/3.0/). 